\title{
MAJORIZATION RESULTS FOR SOME CLASSES OF MULTIVALENT FUNCTIONS
}

\author{
A. O. Mostafa and M. K. Aouf
}

\begin{abstract}
In this paper we obtain some majorization results for some classes of multivalent functions defined by certain differential operator.

Mathematics subject classification (2010): 30C45.

Keywords and phrases: Multivalent functions, majorization, subordination, differential operator.
\end{abstract}

\section{REFERENCES}

[1] O. Altintaş, Ö. ÖZKAN AND H. M. SRIVAStava, Majorization by starlike functions of complex order, Complex Variable, 46 (2001), 207-218.

[2] O. AltintaŞ AND H. M. SRIVASTAVA, Some majorization problems associated with p-valently starlike and convex functions of complex order, East Asian Math. J., 17 (2001), no. 2, 207-218.

[3] S. Akbulut, E. Kadioglu And M. Özdemir, On the subclass of p-valently functions, App. Math. Comput., 147 (2004), no. 1, 89-96.

[4] M. K. AouF, On certain multivalent functions with negative coefficients defined by using a differential operator, Indian J. Math., 51 (2009), no. 2, 433-451.

[5] M. K. Aouf, Generalization of certain subclasses of multivalent functions with negative coefficients defined by using a differential operator, Math. Comput. Modelling, 50 (2009), no. 9-10, 1367-1378.

[6] M. K. Aouf And A. O. Mostafa, On a subclass of n-p-valent prestarlike functions, Comput. Math. Appl., (2008), no. 55, 851-861.

[7] M.-P. Chen, H. IRMAK AND H. M. SRIVAstaVa, Some multivalent functions with negative coeffcients defined by using a differential operator, PanAmer. Math. J., 6 (1996), no. 2, 55-64.

[8] P. Goswami, M. K. Aouf, Majorization properties for certain classes of analytic functions using the Sălăgean operator, Appl. Math. Letters, 23 (2010), no. 11, 1351-1354.

[9] P. Goswami, B. Sharma And T. BulboacĂ, Majorization for certain classes of analytic functions using multiplier transformation, Appl. Math. Letters, 23 (2010), 633-637.

[10] S. P. GoYal And P. Goswami, Majorization for certain classes of analytic functions defined by fractional derivatives, Appl. Math. Letters, 22 (2009), no. 12, 1855-1858.

[11] M. Kamali AND H. ORHAN, On a subclass of certian starlike functions with negative coef cients, Bull. Korean Math. Soc., 41 (2004), no. 1, 53-71.

[12] T. H. MacGreogor, Majorization by univalent functions, Duke Math. J., 34 (1967), 95-102.

[13] S. S. Miller And P. T. Mocanu, Differential Subordination: Theory and Applications, Series on Monographs and Textbooks in Pure and Applied Mathematics, Vol. 225, Marcel Dekker, New York and Basel, 2000.

[14] M. A. NASR AND M. K. Aouf, Starlike function of complex order, J. Natur. Sci. Math., 25 (1985), $1-12$.

[15] Z. NehaRI, Conformal Mapping, McGraw-Hill Book Company, New York, Toronto, London, 1952.

[16] M. S. Robertson, On the theory of univalent functions, Ann. of Math. J., 37 (1936), 374-408.

[17] G. S. SăLĂGEAN, Subclasses of univalent functions, Lecture Notes in Math., 1013, Springer Verlage, Berlin, (1983), 362-372.

[18] H. M. SRivastava, M. K. Aouf And S. Owa, Certain classes of Multivalent functions of order $\alpha$ and type $\beta$, Bull. Soc. Math. Belg., Ser. B, 42 (1990), no. 1, 31-66. 
[19] P. Wiatrows Ki, On the coefficients of some family of holomorphic functions, Zeszyty Nauk. Uniw. Lodz. Nauk. Mat.-Przyrod, 39 (1970), no. 2, 75-85. 